\title{
NEW TAXA IN PECTIS (COMPOSITAE: PECTIDINAE) FROM MEXICO AND THE SOUTHWESTERN UNITED STATES ${ }^{1}$
}

\author{
DAvid J. KeIL \\ Keil, D. J. (Department of Botany, The Ohio State University, Columbus, \\ Ohio).
}

This paper is the first of a series of investigations on the systematics of Pectis L., the largest genus in the subtribe Pectidinae of the tribe Helenieae. Pectis consists of about one hundred species of annual or perennial, glandular-dotted, yellow-rayed herbs that are widespread in the warmer parts of the New World. In the present report three previously unrecognized taxa from Mexico and the southwestern United States are described as new, and a new combination also is made.

\section{Pectis minutiflora Keil, sp. nov. Fig. 1}

Plantae annuae. Caules usque ad $15 \mathrm{~cm}$ longi, ramosissimi, saepe pseudodichotomi, 6-angulosi, glabri, plerumque glandibus oleosis ellipticis vel ovatis in seriebus verticalibus punctati. Folia linearia vel anguste oblanceolata, $0.5-2.5 \mathrm{~cm}$ longa, $1-2.5 \mathrm{~mm}$ lata, uninervia, mucronata, prope bases 2-4 paribus ciliorum usque ad $2 \mathrm{~mm}$ longorum ciliata, margine scaberula vel glabrata, in superficiebus ambabus glabra, supra atrovirentia, subtus pallentia, glandibus oleosis circularibus $0.2-0.3 \mathrm{~mm}$ diametro in seriebus submarginalibus (interdum cum aliquot glandibus additis dispersis) punctata. Pedunculi filiformes, $8-15 \mathrm{~mm}$ longi, interdum glandibus oleosis ovatis vel ellipticis punctati, bracteolati; bracteolae 3-6, alternae, lanceolatae, $0.5-2 \mathrm{~mm}$ longae, attenuatae, hyalinae, interdum margine purpurascentes, saepe 1-2 glandibus oleosis punctatae. Capitula solitaria vel pauca, terminalia aut axillaria, campanulata, $2.5 \mathrm{~mm}$ alta, 1.5-2.5 mm diametro. Phyllaria 5, uniserialia, obovata, $2 \mathrm{~mm}$ longa, $1 \mathrm{~mm}$ lata, marginibus imbricatis, ad apices hyalinis, purpurascentibus, ciliolatis, costis incrassatis, basi gibbosis, in costis et prope apices 3-6 glandibus oleosis ellipticis punctata. Flosculi radii 5; corollae flavae, $1.2 \mathrm{~mm}$ longae, tubis $0.5 \mathrm{~mm}$ longis et ligulis $0.7 \mathrm{~mm}$ longis, glabrae, ad apices tridenticulatae; styli cum stigmatibus linearibus usque ad $1.2 \mathrm{~mm}$ longi. Flosculi disci 14-19; corollae flavae, 1-1.2 mm longae, glabrae, sub-bilabiatae, lobis erectis $0.05-0.15 \mathrm{~mm}$ longis; stigmata minute bifida, vix exserta. Achenia cylindrica vel anguste clavata, $1.2-1.3 \mathrm{~mm}$ longa, glabra vel strigillosa. Pappus fimbriato-coroniformis vel absens. Chromosomatum numerus ignotus.

Type: MEXICO: Chiapas: Jalisco [Jalisco Arriaga, $16^{\circ} 14^{\prime} \mathrm{N}, 93^{\circ} 53^{\prime} \mathrm{W} ; 65$ m (Sousa Sánchez, 1969)], Sep 1923, C. A. Purpus 9162 p. p. maj. (HolotyPe: GH; ISOTYPES: F, MO, NY, UC, US).

Distribution: Known only from two collections from the coastal plain of southeastern Oaxaca and southwestern Chiapas.

Pectis minutiflora is unique in the genus in having both tiny heads and numerous 


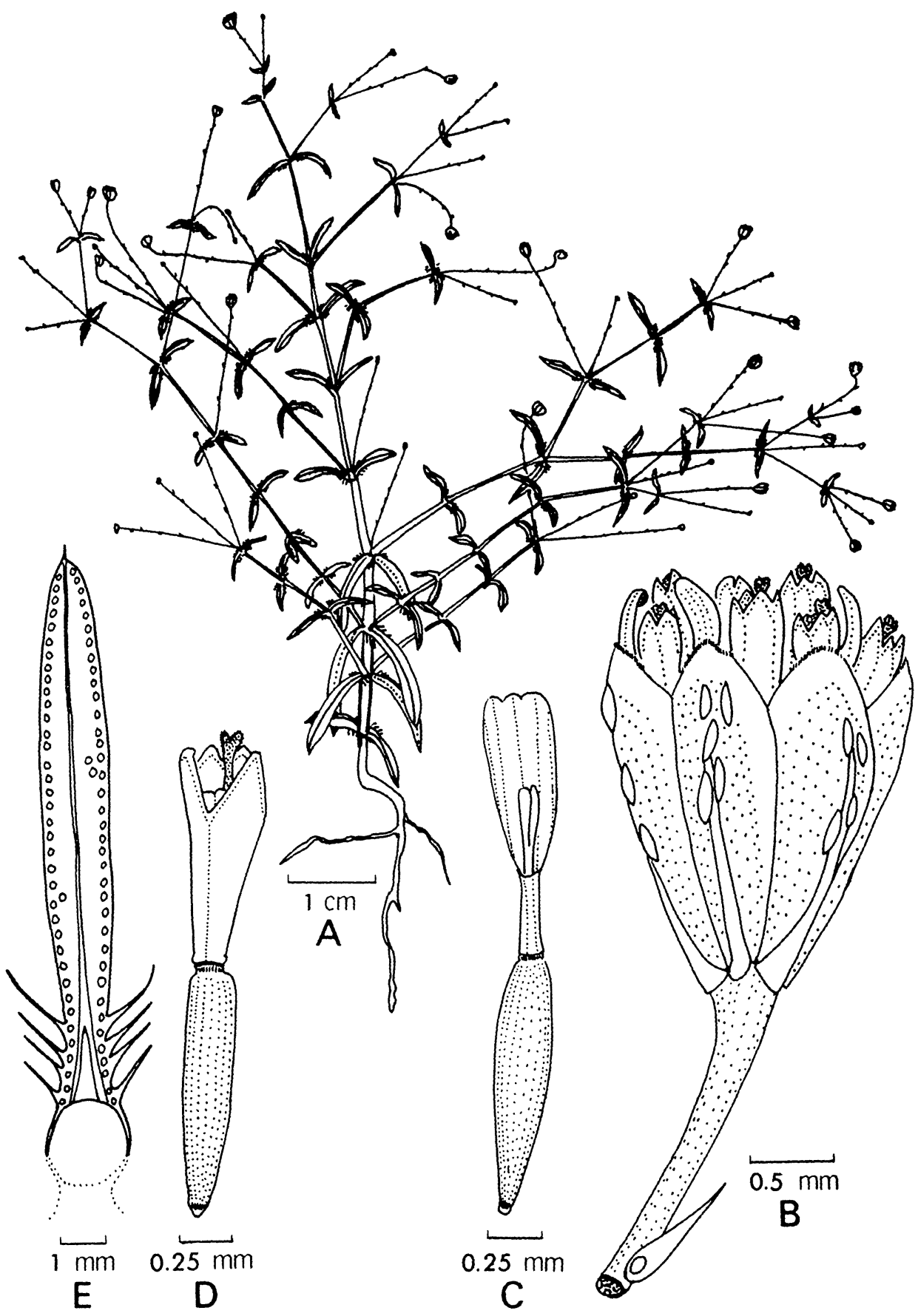

FIG. 1. Pectis minutiflora (drawing based on Purpus 9162): A, habit; B, head; C, ray floret; $\mathrm{D}$, disc floret; E, leaf, abaxial surface. 
minute disc florets. This new species is most similar to $P$. bonplandiana H.B.K. and to $P$. swartziana Less., but $P$. minutiflora differs from both in having smaller heads and florets, fewer phyllaries and ray florets, and submarginal rather than scattered foliar oil glands. The differences among these species are summarized below:

\begin{tabular}{lccc} 
& P. bonplandiana & P. minutiflora & P. swartziana \\
\hline Foliar oil glands & scattered & submarginal & scattered \\
Phyllary number & $6-8$ & 5 & $6-8$ \\
Phyllary length $(\mathrm{mm})$ & $4-4.5$ & 2 & 4 \\
Ray floret number & $6-8$ & 5 & $6-8$ \\
Ray corolla length (mm) & $2-3$ & 1.2 & $2.5-4$ \\
Disc floret number & $12-15$ & $14-19$ & $4-9$ \\
Disc corolla length (mm) & 2 & $1-1.2$ & 2 \\
Disc pappus & 2 series of & fimbriate & $0-2$ bristles \\
& bristles, ex- & crown or & \& fimbriate \\
& panded at base & absent & crown \\
\hline
\end{tabular}

The type of $P$. minutiflora, $C$. A. Purpus 9162, is a mixed collection including a diminutive form of $P$. uniaristata DC. The collection was originally identified and distributed by T. S. Brandegee as this latter taxon. Although all sheets examined contain mixtures of the two taxa, $P$. minutiflora is easily distinguished from $P$. uniaristata by its obtuse rather than acute phyllaries, smaller and more numerous disc florets, and submarginal oil glands. King 1830 is also a mixed collection of the same two taxa.

Additional specimen examined: MEXICO: OAXACA: Open grazed areas 10-12 km E of Niltepec along Rte 190, 18 Jul 1959, King 1830 p.p. (TEX).

Pectis papposa Harv. \& Gray in Gray, Mem. Amer. Acad. Arts 4: 62. 1849. var. grandis Keil, var. nov.

Plantae annuae, glabrae. Caules usque ad $30 \mathrm{~cm}$ longi. Folia linearia, 2-6 cm longa, 1-2 mm lata. Pedunculi 1-3 cm longi, bracteolis 2-6. Capitula numerosa, 10-15 mm alta, 10-15 mm diametro. Phyllaria 8 (raro 7, 9, vel 10), 5-8 mm longa, 1-1.7 mm lata, anguste hyalino-marginata, glandibus 1-5 subterminalibus etiam 4-10 submarginalibus punctata. Flosculi radii 8 (raro 7, 9, vel 10); corollae 5-8 mm longae, glabrae vel parce glanduloso-puberulae. Flosculi disci 12-24 (-34); corollae 3-5 $\mathrm{mm}$ longae, glabrae vel glanduloso-puberulae. Achenia cylindrica, 3-5.5 mm longa. Pappus acheniorum radii coroniformis, ca. $0.2 \mathrm{~mm}$ longus, raro 1 vel pluribus angustis paleis aut setis usque ad $2 \mathrm{~mm}$ longis compositus. Pappus acheniorum disci setaceus vel raro coroniformis; setae 16-24, barbellatae, (2-)3-4 mm longae. Chromosomatum numerus: $n=12$.

Type: UNITED STATES: Texas: Presidio Co.: 3 mi E of jctn US Rte 67 on Texas Rte 170, E of Presidio, 15 Aug 1971, L. A. McGill \& D. Keil 7768 (holotype: US; ISOTYPES: ARIZ, ASU, ENCB, F, GH, MICH, MO, NY, OS, RSA, SMU, TEX, $\mathrm{UC})$.

Distribution: Known from southern New Mexico and southwestern Texas to northern Coahuila and Chihuahua; disjunct populations also occur in northern and southern Arizona and in northeastern New Mexico (Fig. 2).

Plants of Pectis papposa var. grandis are usually larger and less densely branched than those of var. papposa. The heads of var. grandis are longer-peduncled, usually contain more disc florets, and have larger phyllaries and florets than those of var. papposa. There is some overlap between the larger extremes of var. papposa and the smaller extremes of var. grandis, but usually the two varieties are easy to distinguish. The dissimilarities between the two varieties persist in plants grown from 


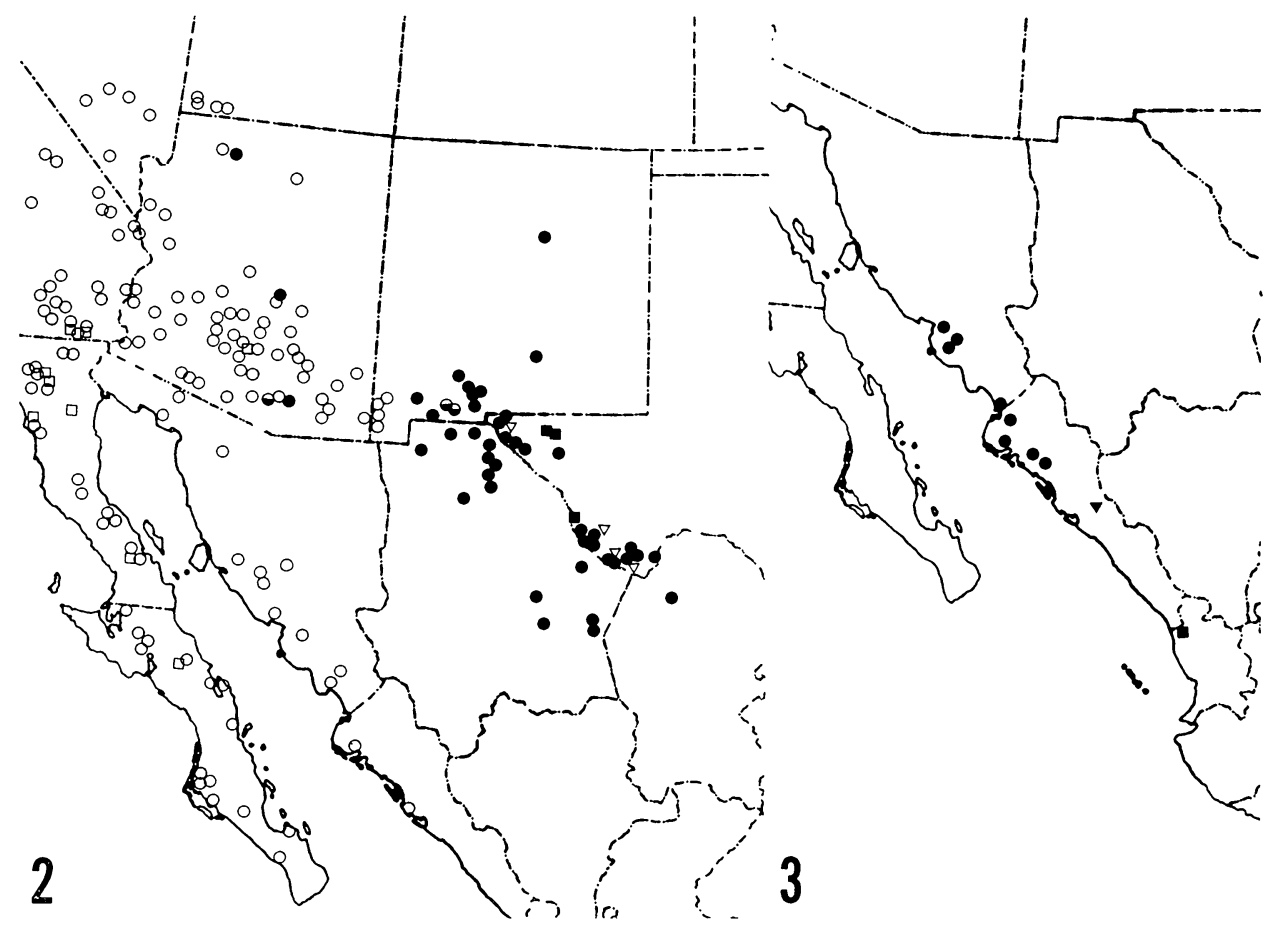

Figs. 2, 3. Distribution of Pectis papposa and P. purpurea. Fig. 2. Open circles, P. papposa var. papposa, pappose individuals; open squares, var. papposa, epappose individuals; closed circles, var. grandis, pappose individuals; closed squares, var. grandis, epappose individuals; half-filled circles, intermediates between var. papposa and var. grandis; triangles, hybrids between var. grandis and $P$. angustifolia. Fig. 3. Circles, P. purpurea var. sonorae; triangle, var. purpurea; square, var. lancifolia.

seed under controlled environmental conditions (Keil, unpubl.), which suggests that the differences observed are under genetic control. Contrasting characteristics of the two varieties are listed below:

var. papposa

var. grandis

Peduncle length $(\mathrm{mm})$

Phyllary length $(\mathrm{mm})$

Ray corolla length $(\mathrm{mm})$

Ray achene length $(\mathrm{mm})$

Disc floret number

Disc corolla length $(\mathrm{mm})$

Disc pappus length $(\mathrm{mm})$

\begin{tabular}{cc}
$3-10(-25)$ & $10-40$ \\
$3-5$ & $5-8$ \\
$3-6$ & $5-8$ \\
$2.5-4.5$ & $4-5.5$ \\
$6-14(-18)$ & $12-24(-34)$ \\
$2-3.5(-4)$ & $(3-)) 3.5-5.5$ \\
$1.5-2.5$ & $2.5-4$ \\
\hline
\end{tabular}

Pectis papposa var. grandis has a more easterly distribution than does var. papposa. With the exception of three disjunct populations of var. grandis in Arizona, the varieties occupy different geographic ranges. Typical $P$. papposa occurs mostly in the Sonoran and Mojave Deserts, whereas var. grandis is for the most part restricted to the Chihuahuan Desert. A few specimens from southeastern Arizona and southwestern New Mexico (McGill \& Keil 8456; Mulford 1079; Sherff s.n., 5 Sep 1908) appear to be somewhat intermediate between the two varieties and cannot easily be assigned to either. 
TABLE I

NeW CHROMOSOME COUNTS For Pectis

\begin{tabular}{|c|c|c|}
\hline Taxon & Locality and Voucher* & $\begin{array}{l}\text { Chromosome } \\
\text { number }(n)\end{array}$ \\
\hline \multirow[t]{4}{*}{$\begin{array}{l}\text { P. papposa Harv. \& Gray } \\
\text { var. grandis Keil }\end{array}$} & $\begin{array}{l}\text { New Mexico: Dona Ana Co.: } 1 \mathrm{mi} \mathrm{N} \text { of } \\
\text { Hatch exit on I- } 25 \text {, Keil } 7653\end{array}$ & 12 \\
\hline & $\begin{array}{l}\text { Texas: Presidio Co.: } 3 \mathrm{mi} \mathrm{E} \text { of jctn US } \\
67 \text { on Texas } 170, \text { McGill } \& \text { Keil } 7768\end{array}$ & 12 \\
\hline & $\begin{array}{l}\text { Texas: Presidio Co.: } 15.2 \mathrm{mi} \mathrm{NW} \text { of } \\
\text { Lajitas, } M c \text { Gill } \mathcal{E} \text { Keil } 7786\end{array}$ & 12 \\
\hline & $\begin{array}{l}\text { Chinuahua: } 24.5 \mathrm{mi} \mathrm{N} \text { of Janos, McGill } \\
\text { E Keil } 8431\end{array}$ & 12 \\
\hline \multirow[t]{3}{*}{$\begin{array}{l}P . \text { purpurea Brandeg. } \\
\text { var. sonorae Keil }\end{array}$} & $\begin{array}{l}\text { SONORA: } 1.9 \mathrm{mi} \mathrm{NW} \text { of Vicam, Canne } \mathcal{E} \\
\text { Keil } 8644\end{array}$ & 12 \\
\hline & $\begin{array}{l}\text { SinALOA: } 14.5 \mathrm{mi} \mathrm{S} \text { of Sonora-Sinaloa } \\
\text { boundary, Canne } \mathcal{E} \text { Keil } 8737\end{array}$ & 12 \\
\hline & $\begin{array}{l}\text { SINALOA: } 10 \mathrm{mi} \mathrm{NW} \text { of Río Sinaloa on } \\
\text { Mexico } 15 \text {, Canne } \mathcal{E} \text { Keil } 8777\end{array}$ & 12 \\
\hline
\end{tabular}

* Voucher specimens are deposited in the Herbarium of the Ohio State University (OS).

In New Mexico, Texas, and northern Mexico, Pectis papposa var. grandis is sympatric with $P$. angustifolia Torr. These taxa may usually be distinguished by a number of features, including shape of leaf bases, length of peduncles, and presence or absence of a setose pappus. Sometimes, however, essentially epappose forms of $P$. papposa (e.g., Waterfall 5203) have been confused with $P$. angustifolia. Additionally, hybridization apparently is occurring in several Texas localities (Keil, unpubl.), which obscures the usually consistent differences between the two taxa.

Chromosome numbers reported by Powell \& Sikes (1970) for Pectis papposa ( $n=12$, plus a regularly occurring centric fragment in some populations) were made from plants referable to var. grandis. The counts made in the present study (Table I) agree with this previous report, although no fragments were observed. Other counts reported previously for P. papposa ( $n=12$; Raven \& Kyhos, 1961) are from plants of var. papposa.

Additional specimens examined: UNITED STATES: Arizona: Coconino Co.: Havasupai Canyon, 17 Jul 1940, Clover 5192 (SMU, TEX); Gila Co.: Mesa near Rock \& Rye Creeks, 15 Aug 1935, Collom 538 (ND); Pima Co.: Santa Rita Mts, 29-31 Aug 1904, Griffiths 7003 (MO). New Mexico: Dona Ana Co.: $1 \mathrm{mi} \mathrm{N}$ of Hatch exit on I-25, 13 Aug 1971, Keil 7653 (ASU, GH, OS, TEX, US) ; Lincoln Co.: Near Hondo, 2 Aug 1967, Cole, Minckley, \& Pinkava 3010 (ASU); Luna Co.: Pancho Villa State Park, 1 Aug 1967, Cole, Minckley, \& Pinkava 3068 (ASU). Texas: Brewster Co.: Tornillo Flats, 28 Jun 1941, Warnock 21681 in part (F, NY, PH, SMU, TEX); Culberson Co.: S of Van Horn, 23 Aug 1962, Jackson 3162 (SMU); El Paso Co.: 2 mi W of Clint, 31 Aug 1967, Massey 1825 (SMU, TEX); Hudspeth Co.: 6 mi W jctn Hwys. 54 \& 62, 20 Jul 1943, Waterfall 5203 (ARIZ, F, GH, MO, NY, SMU, TEX); Presidio Co.: $15.2 \mathrm{mi}$ NW of Lajitas, 15 Aug 1971, McGill $\mathcal{E}$ Keil 7786 (DS, ENCB, OS, RSA, SMU, US). MEXICO: ChIHUAHUA: $37.7 \mathrm{mi} \mathrm{N}$ of Cd. Camargo, 25 Aug 1971, McGill \& Keil 8254 (ASU, F, NY, OS, POM, US); $24.5 \mathrm{mi} \mathrm{N}$ of Janos, 29 Aug 1971, McGill \& Keil 8431 (ARIZ, DS, OS, UC); Vicinity of Fierro, Sierra de Encinillas, 8 July 1941, Stewart 742 (GH). Coahuila: Near Rancho Las Norias, 21 Aug 1966, Powell, Scudday, E Sikes 1445 (TEX). 
Pectis purpurea Brandeg. Zoe 5: 225. 1905. var. sonorae Keil, var. nov.

Plantae annuae, glabrae vel dense puberulae. Caules usque ad $50 \mathrm{~cm}$ longi. Folia linearia vel lanceolata, $1.5-6 \mathrm{~cm}$ longa, $2.5-9 \mathrm{~mm}$ lata, obtusa vel acuta, mucronata, basi 1-3 paribus ciliorum ciliata, subtus glandibus oleosis submarginalibus punctata. Pedunculi 4-13 cm longi, bracteolis 4-20. Capitula 10-15 mm alta, 10-20 mm diametro. Phyllaria 8, obtrullata, 5-6.5 mm longa, 1.8-3 mm lata, 4-12 glandibus dispersis punctata. Flosculi radii 8; corollae flavae, interdum rubro-nervatae, 9-11.5 $\mathrm{mm}$ longae, glanduloso-puberulae. Flosculi disci 40-50; corollae flavae, 4-5 mm longae, glanduloso-puberulae. Achenia 3-4 mm longa, pilosa vel strigillosa. Pappus acheniorum radii biserialis; series interior setacea, setis 2, rigidis, usque ad $3 \mathrm{~mm}$ longis, series exterior squamosa, brevior, squamellis 1-4, angustis, interdum in 5-10 setis brevibus gracilibus divisis. Pappus acheniorum disci biserialis; series interior setacea, setis 5-10, rigidis, 4-5 mm longis, antrorse scaberulis, series exterior setacea, brevior, setis 8-20, gracilibus. Chromosomatum numerus: $n=12$.

Type: MEXICO: Sonora: $1.9 \mathrm{mi} \mathrm{NW}$ of Vicam on Mexico Rte 15, ca. $66 \mathrm{mi} \mathrm{SE}$ of Guaymas, 7 Sep 1971, J. M. Canne $\mathcal{E}$ D. Keil 8644 (holotype: US; isotypes: ARIZ, ASU, DES, DS, ENCB, F, GH, MICH, MO, NY, OS, RSA, SD, SMU, TEX, UC).

Distribution: Known from the coastal plain of southern Sonora and northern Sinaloa (Fig. 3).

Pectis purpurea var. sonorae is similar to but readily distinguished from $P$. purpurea var. purpurea by its larger heads and florets, more numerous disc florets, and setaceous rather than coroniform pappus. This last character, under the somewhat artificial systems of Gray (1850) and Fernald (1897), would have necessitated placement of the two taxa into different sections of the genus. However, var. sonorae and var. purpurea are so similar in habit, leaf shape, gland arrangement, and phyllary morphology that, in my opinion, they cannot be regarded as more than varietally distinct. Variety sonorae has a more northerly distribution than the typical variety, which is known only from the vicinity of its type locality in central Sinaloa.

Pectis purpurea var. sonorae and P. rusbyi Greene ex Gray are superficially similar. In fact, two collections, here placed in P. purpurea var. sonorae (Palmer 765, Flyr 107), have been cited as Pectis palmeri Wats. (Fernald, 1897; Turner \& Flyr, 1966), a species recently found to be conspecific with $P$. rusbyi (Keil, unpubl.). Both $P$. purpurea var. sonorae and $P$. rusbyi have linear to lanceolate leaves, 8-rayed heads, and a pappus of capillary bristles. $P$. rusbyi, however, has marginal rather than submarginal foliar oil glands, shorter peduncles, and smaller heads. The phyllaries of $P$. rusbyi are oblong, longitudinally striate, with corky midribs extending nearly to the tips, and with large subterminal oil glands. The phyllaries of $P$. purpurea var. sonorae are angular-obovate, without striae, with the midribs corky only about half the length of the phyllary, and seldom with enlarged subterminal glands. The oils of $P$. rusbyi have a spicy odor, whereas those of $P$. purpurea var. sonorae are distinctly fetid.

The chromosome counts reported here (Table I) agree with that previously reported for this taxon (as P. palmeri: Turner \& Flyr, 1966).

Additional specimens examined: MEXICO: SinaloA: $14.5 \mathrm{mi}$ S of SonoraSinaloa boundary on Mexico 15, 10 Sep 1971, Canne $\mathcal{E}$ Keil 8737 (ASU, NY, OS, RSA, TEX, US); $10 \mathrm{mi}$ NW of Río Sinaloa on Mexico 15, 11 Sep 1971, Canne $\mathcal{E}$ Keil 8777 (ARIZ, DS, ENCB, F, GH, OS); Los Mochis, 22 Sep 1957, Condit s.n. (SD); 57 mi S of Los Mochis on Mexico 15, 28 Jan 1964, Flyr 107 (TEX, WIS). Sonora: Agiabampo, 1890, Palmer 765 (GH, MICH, MO); Oroz, near Río Yaqui, 
7-8 Sep 1935; Pennell 20220 (MICH, NY, PH); 28 mi SE of Guaymas, 18 Aug 1956, Waterfall 12828 (GH).

Pectis purpurea Brandeg. Zoe 5: 225. 1905. var. lancifolia (Greenm.) Keil, comb. nov.

Pectis sinaloensis Fern. var. lancifolia Greenm. Proc. Amer. Acad. Arts 40: 50.1904.

Pectis lancifolia (Greenm.) Rydb. North Amer. Flora 34: 203. 1916.

Type: MeXico: Territorio de Tepic [Nayarit]: Between Concepción \& Acaponeta, 19 Jul 1897, J. N. Rose 1893 (LEctotype: GH!; Isotypes: GH! US!).

The recognition of Pectis purpurea var. sonorae necessitates a reevaluation of the status of $P$. lancifolia. Prior to the discovery of the new variety, the differences between $P$. purpurea and $P$. lancifolia seemed sufficient to maintain them as distinct species. The two taxa differ in pubescence, leaf shape, head size, number of disc florets, and in pappus structure. However, the new variety, P. purpurea var. sonorae, was found to be much more similar to $P$. lancifolia than is the typical $P$. purpurea. The former two taxa have similar sizes of heads and numbers of disc florets, but they differ in leaf shape and in pappus structure. The most pubescent extremes of $P$. purpurea var. sonorae approach $P$. lancifolia in this respect. Because the differences between these taxa seem insufficient for the recognition of distinct species, $P$. lancifolia is here reduced to varietal rank under $P$. purpurea.

As an aid to understanding the relationships just discussed, the following key is provided to help differentiate the three varieties of Pectis purpurea:

1. Pappus in one series, coroniform, ca. $0.3 \mathrm{~mm}$ long; phyllaries $4-4.8 \mathrm{~mm}$ long; disc florets 20-40 - var. purpurea.

1. Pappus in two series, the inner of stiff bristles to $4.5 \mathrm{~mm}$ long, the outer of slender bristles or flattened fimbriate pales to $2 \mathrm{~mm}$ long; phyllaries 5-6.5 mm long; disc florets $40-50$

2. Outer pappus of slender bristles; leaves with 1-3 pairs of marginal cilia; foliar oil glands in submarginal rows var. sonorae.

2. Outer pappus of flattened fimbriate pales; leaves usually with 4-6 pairs of marginal cilia; foliar oil glands submarginal and scattered var. lancifolia.

\section{ACKNOWLEDGMENTS}

I am grateful to Drs. Tod F. Stuessy and Donald J. Pinkava for critically reading the manuscript and for their comments and suggestions. Thanks also go to Miss Judith M. Canne and Mr. Lyle A. McGill for their assistance in the field. Support of the National Science Foundation (Dissertation Research Grant GB:30240) for the field studies is gratefully acknowledged.

\section{LITERATURE CITED}

Fernald, M. L. 1897. A systematic study of the United States and Mexican species of Pectis. Proc. Amer. Acad. Arts 33 : 57-86.

Gray, A. 1850. Plantae Wrightianae Texano-Neo-Mexicanae. I. Smithsonian Contr. Knowl. 3(5): 1-146.

Powell, A. M. \& S. Sikes 1970. Chromosome numbers of some Chihuahuan Desert Compositae. Southwestern Nat. 15: 175-186.

Raven, P. H. \& D. W. Kyhos 1961. Chromosome numbers in Compositae. II. Helenieae. Amer. J. Bot. 48: 842-850.

Sousa Sánchez, M. 1969. Las colecciones botánicas de C. A. Purpus en México. Período 18981925. Univ. Calif. Publ. Bot. 51 : 1-36.

Turner, B. L. \& D. Flyr 1966. Chromosome numbers in the Compositae. X. North American species. Amer. J. Bot. 53 : 24-33. 